\title{
IMPACT OF THE CAR SCRAPPING SCHEME ON CONSUMER BEHAVIOUR AND AGGREGATE CONSUMPTION
}

\author{
Lukáš Mohelský*
}

\begin{abstract}
The American financial crisis, which started in 2007 , triggered subsequently a global economic decline. To boost the decreasing national economies, many countries introduced various stipulating measures. The automotive industry has been among the numerous fields, which were affected by the decline. The proclaimed importance of this industry led to the introduction of a new economic tool to support the short-term consumption, usually referred to as the car scrapping scheme. This scheme stands for a special incentive to purchase a new car. Usually, the incentive is introduced in the form of a direct financial support or an ex-post tax relief, and is conditioned by scrapping the applicant's old car. The microeconomic analysis of consumer behaviour proved that the car scrapping scheme can mitigate the maximum decline of the aggregate consumption, thanks to the shift of the consumption line and of the map of the indifference curves. However, the car scrapping scheme has many other impacts, whose research should be elaborated.
\end{abstract}

Keywords: car scrapping scheme, automotive industry, consumer behaviour, microeconomics

JEL Classification: D11, D31

\section{Introduction}

The financial crisis ended in December 2007 the 73 month long period of economic expansion in the United States and the world's biggest economy turned into recession. ${ }^{1}$ Thus, the originally financial crisis became an economic one. In the following months the crisis reached global dimension and caused economic decline in many countries around the globe.

The recession brought, among other, a new economic tool focused on the stimulation of the aggregate demand in the time of economic decline. The car scrapping scheme (known under various names on the national levels) represents a measure to stipulate the demand for new cars, which was introduced globally as a part of the packages aimed to heal the national economies.

* Lukáš Mohelský, University of Economics, Prague, nám. W. Churchilla 4, CZ - 130 67, Praha 3 (lukasmohis@yahoo.com). The article is a part of the research activities of the Faculty of International Relations financed with institutional support for the development of research organization.

This paper won the $3^{\text {rd }}$ prize in the PAPER' 10 contest announced by the Czech University of Economics in Prague.

1 National Bureau of Economic Research (2008). 
Even though the incentives to purchase new vehicles have been known from the past, they have never been intended to support the private demand to such an extent. The program's unprecedentness and the emergency of the situation caused that only limited number of analyses had been elaborated. It is slightly surprising that even nowadays the amount of analyses available remains quite low. ${ }^{2}$

This paper consists of five consecutive chapters. The initial one deals with the definition of the car scrapping scheme. The second chapter is focused on the analysis of consumer's behaviour, and its crucial part describes the distribution of consumers into three groups based on their behaviour during the economic crisis. The (micro) economic effects of the car scrapping scheme both on the consumer behaviour and on the consumers' groups are analyzed in the third chapter. The beginning of Chapter 4 describes the number of the applicants in the car scrapping scheme. This chapter further covers the aggregation of the effects on the consumption as a whole. Eventually in the fifth chapter, the proven effects are summarized and a list of other impacts, which deserve more research, is briefly mentioned. ${ }^{3}$

\section{Car Scrapping Scheme - Incentive for Purchase of a New Car}

The car scrapping scheme as a special incentive to purchase a new car was introduced in many countries as a reaction to the global economic downturn. This tool was applied in different ways, usually as a direct financial support provided by government (for example in Cyprus, Germany or the United States) or as an ex-post tax relief (China, South Korea), and its exploitation was conditioned by scrapping of an older vehicle (the exact rules differed by country). The main aim of the scheme was to stipulate the consumption through the sales of new cars and thus to help the economy to recover. The introduction of the car scrapping scheme may also have further, auxiliary objectives, such as the employment support, or reduction of environmental impact of the road transportation.

\section{Key Features of Consumer Behaviour}

\subsection{Utility Maximization under Budget Constraint}

In their everyday lives consumers demand a number of various goods. In their decisionmaking they are basically led by two main indicators - the price and the (subjective) utility, which stems from the consumption.

Finding the consumer's equilibrium thus resides either in finding the combination of goods delivering the highest utility at the given budget, or alternatively in finding the lowest budget, which can assure the desired level of utility. In this study, I stick to the former alternative.

2 See for example the Council of Economic Advisors (2008), Höpfner (2009), Läufer (2009), MHSR (2009).

3 All charts and tables were created by the author. 
Graph 1

General consumer's equilibrium

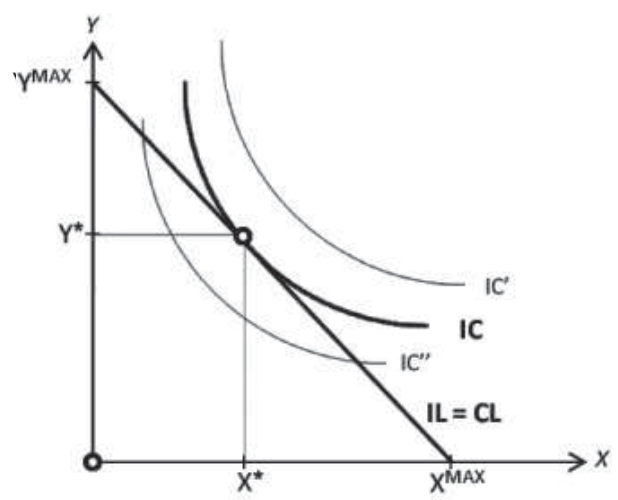

Graph 2

Consumer's equilibrium - Pessimist consumers after beginning of economic downturn

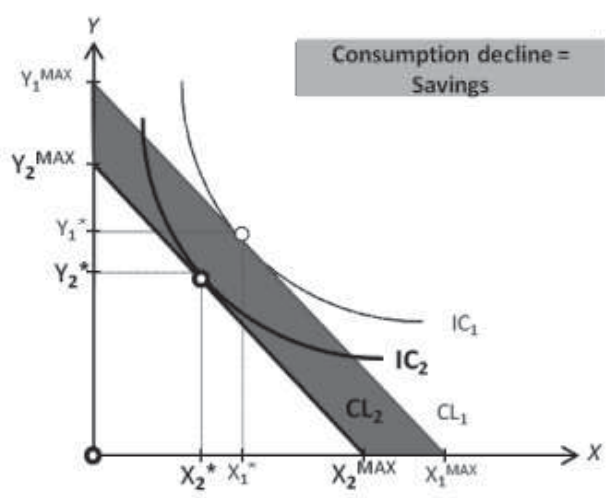

In the graphical expression, which contains the number of the theoretically available goods $\mathrm{X}$ and $\mathrm{Y}$ on the axis ${ }^{4}$, every indifference curve $\mathrm{IC}^{5}$ represents such a combination of $\mathrm{X}$ and $\mathrm{Y}$ consumption that brings the same level of utility. The income line IL stands for the highest attainable combination of $\mathrm{X}$ and $\mathrm{Y}$ that can be obtained under the given budget. If the consumers use all their income on the consumption, the IL is identical with the consumption line CL. If the consumers decide to save part of their income, the actual CL lies under the IL, and vice versa for spending previously saved means.

\subsection{Consumer Behaviour before Economic Downturn}

During this period, the total consumers' income is used for their consumption.

\subsection{Consumer Behaviour after Beginning of Economic Downturn ${ }^{6}$}

\section{Groups of consumers according to reaction on economic downturn}

The reaction on the expected and subsequently actual economic downturn is not identical for all consumers. Let the wide scale of possible reactions be divided into three main groups:

(a) Some consumers lower their consumption based on their fears about the future development, even though their income level remains intact

NPC ... Number of pessimist consumers

(b) Some consumers lower their consumption due to the loss of employment, which makes their income decline

NUC ... Number of unemployed consumers

4 For the sake of illustration the two goods model is applied.

5 The rationale of the indifference curves shape is provided for instance by Ferguson (1972) or Nicholson (1989).

6 This part also describes the behaviour of consumers, who modify their consumption patterns even before the actual beginning of the downturn due to their negative expectations (see text for further explanation). 
(c) Rest of consumers does not react on the change of the economy cycle NIC ... Number of intact consumers

Let us further assume that the total amount of consumers doesn't change and that every consumers is member of one and only group.

\section{Behaviour of pessimist consumers}

Pessimist consumers change their behaviour due to the expected, but currently non-existent economic downturn. The change is characterised by lowering of consumption, (and rise of savings), which will enable them to cope with the expected recession. ${ }^{7}$

This behaviour can be marked as the self-fulfilling prophecy ${ }^{8}$ or the Placebo effect. ${ }^{9}$ If the consumers lower the consumption without any actual decline in income and further, due to their pessimism, either don't put their money into banks or put the money into banks, whose behaviour (or behaviour of part of them) corresponds with the consumers behaviour, not only the aggregate consumption sinks, but also the amount of money in circulation declines. Negative expectations and the mistrust in a well-functioning system have the power to bring such a system to collapse (see, for instance, the recession of the American economy in $1990^{10}$ ).

As the pessimist consumers lower their consumption voluntarily, no changes of their preferences and the prices are expected, which leads to the proportional decline of consumption of both goods.

The consumption line $\mathrm{CL}_{2}$ lies below the income line IL, which remains on the level of the original $\mathrm{CL}_{1}$.

\section{Behaviour of unemployed consumers}

Unemployment is (among other consequences) linked with the decline of the available income. Therefore, the consumption of the unemployed consumers must be lower, which is not accompanied by any growth of savings.

Graph 3

Consumer's equilibrium - Unemployed consumers after beginning of economic downturn

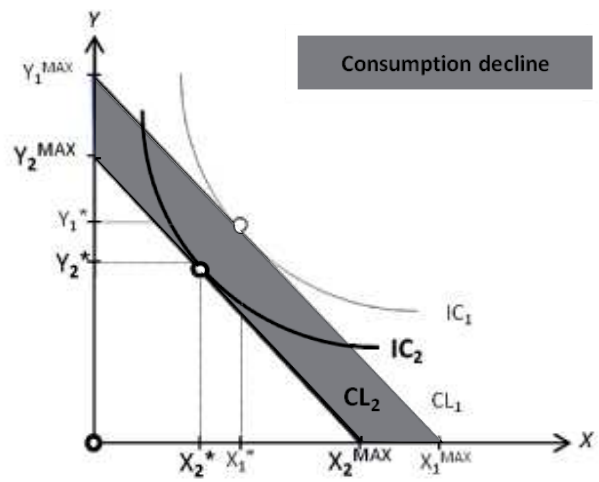

7 Brown (2006), Browning (1996)

8 Biggs (2009), Li (2006), Rosenwald (2009)

9 Hashish (1988)

10 Blanchard (2006) 
Correspondingly with the previous case, no further changes in consumption preferences or goods prices are assumed.

\section{Behaviour of intact consumers}

The intact consumers, who do not react in any way to the economic fluctuations, do not change their consumption habits and follow the pre-crisis pattern.

\subsection{Consumer's Behaviour after the End of Economic Downturn ${ }^{11}$}

\section{Behaviour of pessimist consumers}

As soon as the negative expectations fade away, these consumers shift their behaviour. Let us assume that firstly there is a shift to the same consumption pattern applied before (the consumer's equilibrium returns to the original pre-crisis position), and that secondly the financial means saved in the time of pessimism are spent after a given period, when the confidence continues to grow. It is also assumed that the savings are spent for twice as long period as they were accumulated.

\section{Graph 4}

Consumer's equilibrium - Pessimist consumers during the time of savings spending

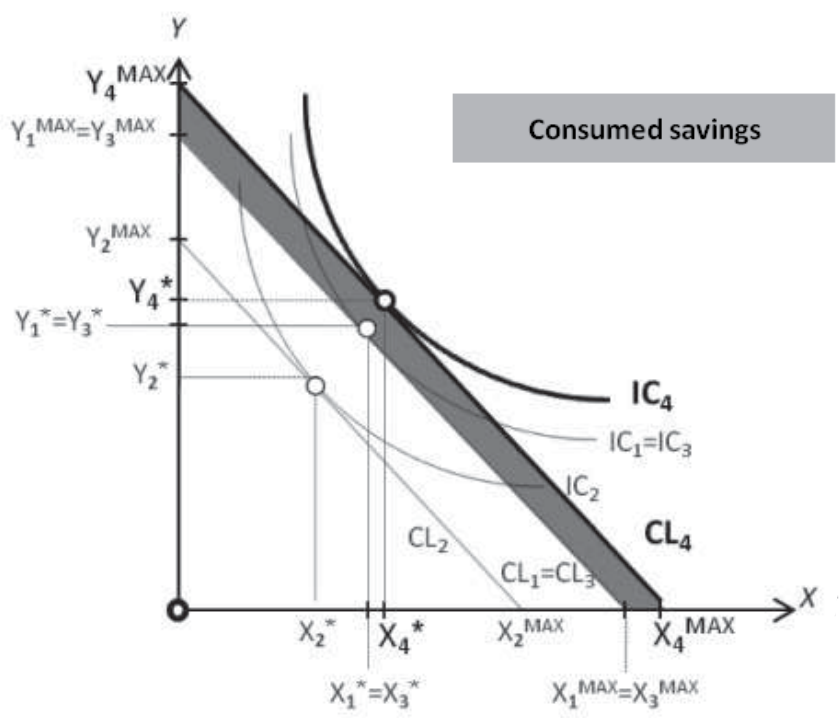

The consumption line $\mathrm{CL}_{4}$ lies above the income line IL, which remains on the level of the original $\mathrm{CL}_{1}$.

After consuming all the accumulated savings, the consumption pattern returns to the original one.

11 The end of the economic downturn does not necessarily correspond with the change of the consumer behaviour. For the consumers, that were sometime during the recession part of the pessimist group, the chapter deals with the consumption analysis after their pessimism fades away. Similarly, for the consumers that were anytime during the recession part of the unemployed group, the chapter deals with the consumption analysis after they find new employment. 


\section{Behaviour of unemployed consumers}

Having found a new position, the consumers from this group shift their consumption pattern back to the original one.

\section{Behaviour of intact consumers}

The intact consumers don't change their consumption habits in any way.

\subsection{Development of Consumers Groups Number in Time ${ }^{12}$}

\section{Number of pessimist consumers}

The consumer sentiment is one of the indicators, whose development serves as barometer of economic activity, as it captures the expected tendencies of consumption, which may significantly help in forecasting the economy trends. ${ }^{13}$

Let us assume that the GDP starts decreasing in time $t_{1}{ }^{G D P}$. Thus, there is time $\mathrm{t}_{1}{ }^{\text {Sentiment }}$, which precedes it and marks the beginning of the sentiment recession. Correspondingly, in $\mathrm{t}_{2}{ }^{\text {Sentiment }}$ the sentiment starts to grow, which is followed by $\mathrm{t}_{2}{ }^{\mathrm{GDP}}$ that marks the economic upheaval. Let us further assume times $\mathrm{t}_{3}{ }^{\text {Sentiment }}$ and $\mathrm{t}_{3}{ }^{\mathrm{GDP}}$, which mark the return of the underlying variables to their original values.

The analysis of the development in selected countries (the Czech Republic, Germany, the USA) since 2001 revealed that the GDP lags behind the sentiment by about 1-2 quarters, which is in line with the outputs of the Federal Reserve Bank of San Francisco (2008). Therefore, let us assume that the consumer sentiment precedes the GDP development by 2 quarters.

The time passed between the decline and the subsequent growth of GDP (consumer sentiment respectively) can be understood as the length of the economic recession, which according to Claessens (2008) stands at 4 quarters. Based on the above mentioned time lag there is a 2 quarters gap between decline of the GDP and the upheaval of the consumer sentiment.

\section{Graph 5}

Number of pessimist consumer - Key milestones in time

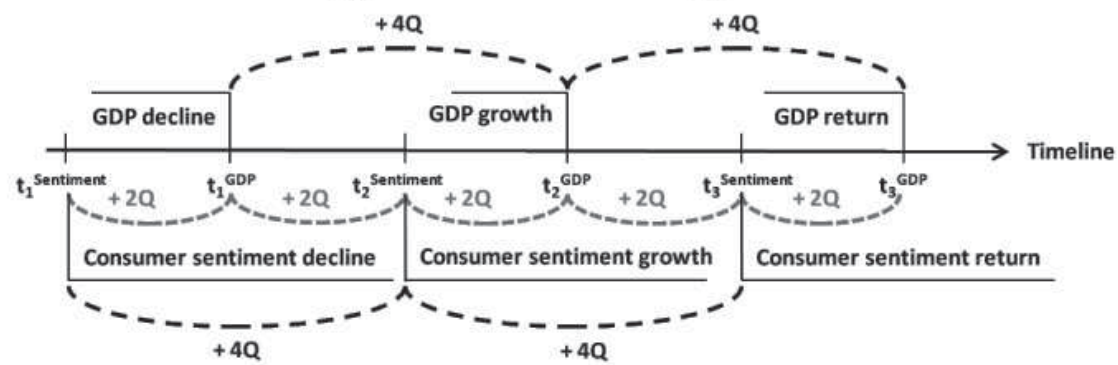

The number of pessimist consumers is not constant in time. Let us assume that the curve representing this number has concave shape and is symmetric with time $t_{2}{ }^{\text {Sentiment }}$ being the break-point.

12 This chapter describes the development of consumer sentiment, GDP and unemployment in time. Whereas the sentiment and unemployment are crucial for the analysis, the GDP development has auxiliary function only.

13 See for example Dion (2006) or Federal Reserve Bank of San Francisco (2008). 
Graph 6

Number of pessimist consumers in time

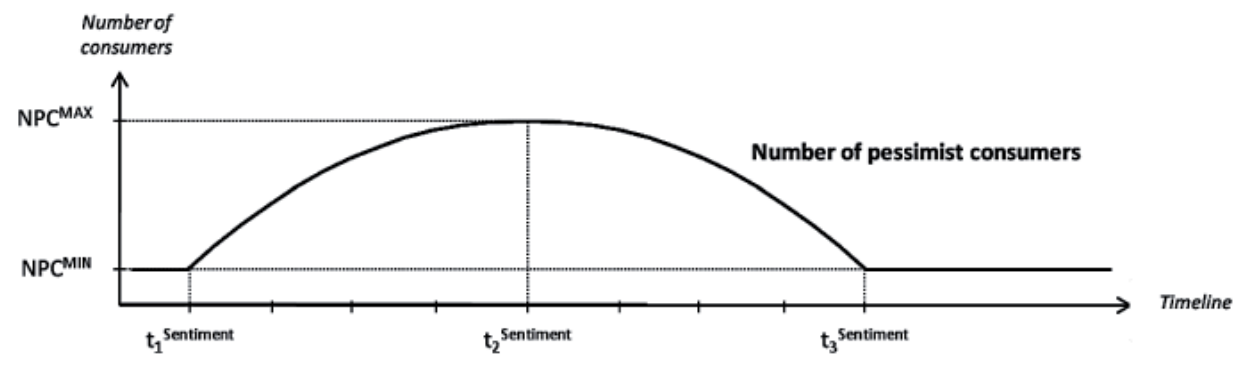

\section{Number of unemployed consumers}

The growth of unemployment is a component of practically every economic downturn, but may differ in scale and duration. Whereas the older recessions were characterised by steep fall of employment and its correspondingly steep growth, the more recent recessions follow the pattern of a sharp increase followed by only a gradual decline. ${ }^{14}$

As already stated before, the time $t_{1}{ }^{G D P}$ represents the start of the GDP decline. Subsequently, the unemployment reacts to the unfavourable development and starts to grow quickly in time $\mathrm{t}_{1}{ }^{\mathrm{Un}}$. The negative economic trajectory is reversed in time $\mathrm{t}_{2}{ }^{\mathrm{GDP}}$, which makes the unemployment curve react in time $t_{2}{ }^{\text {Un }}$. Eventually, the original values are reached in $\mathrm{t}_{3}^{\mathrm{GDP}}$ and $\mathrm{t}_{3}^{\mathrm{Un}}$.

The data analysed represent too short period to provide useful results for this sake. Therefore, the conclusions of Knotek (2009) and Mankiw (2007) are accepted. Both authors claim that the unemployment usually starts to grow in the same quarter as the GDP declines $\left(\mathrm{t}_{1}{ }^{\mathrm{GDP}}=\mathrm{t}_{1}{ }^{\mathrm{Un}}\right)$ and the pace of the unemployment growth rises followingly. However, the unemployment shows uneven elasticity. There are no generally applicable lengths of the periods between the particular events.

Graph 7

Number of unemployed consumer - Key milestones in time

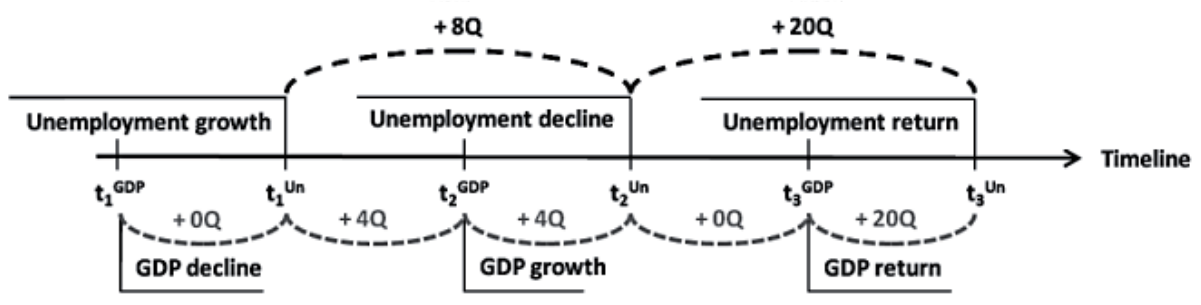

For the sake of this analysis, I assume that the peak of unemployment comes in time $t_{2}{ }^{U n}$ with four quarters delay after the start of the GDP growth $\left(t_{2}{ }^{G D P}\right)$. Since this moment the unemployment takes 20 quarters to reach the original level in time $t_{3}{ }^{G D P}$. 
Graph 8

Number of unemployed consumers in time

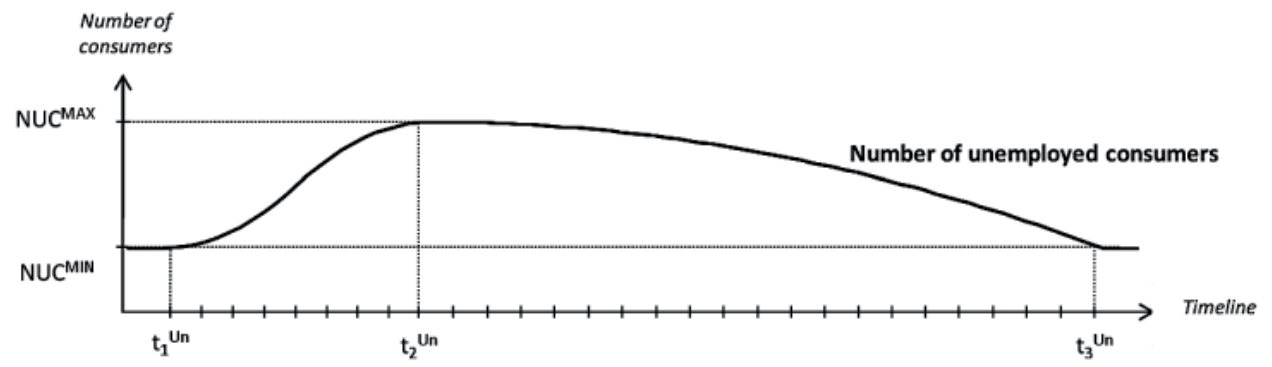

Number of intact consumers

As the total number of consumers is assumed to be stable, the number of intact consumers can be in every moment deduced as number of consumers who are neither pessimist nor unemployed.

The first local minimum of the number of consumers is reached in time $t^{*}$ $\left(t_{2}\right.$ Sentiment; $\left.t_{2}{ }^{U n}\right)$, when the number of pessimist consumers is ,slightly“ behind the peak, whereas the number of unemployed consumers has already started to grow. The second local minimum can be found in time $\mathrm{t}_{2}{ }^{\mathrm{Un}}$, when the number of unemployed consumers reaches its zenith.

The global minimum can thus be experienced either in $t^{*}$ or $t_{2}{ }^{\text {Un }}$ according to the actual numbers of the consumers in the defined groups. As I assume that the number of pessimist consumers is (at its peak) higher than the number of unemployed consumers (at its peak), the number of intact consumers reaches the lowest level in time $t^{*}$. The number returns to the original value in $t_{3}{ }^{\mathrm{Un}}$, together with the number of unemployed consumers.

Graph 9

Number of intact consumers in time

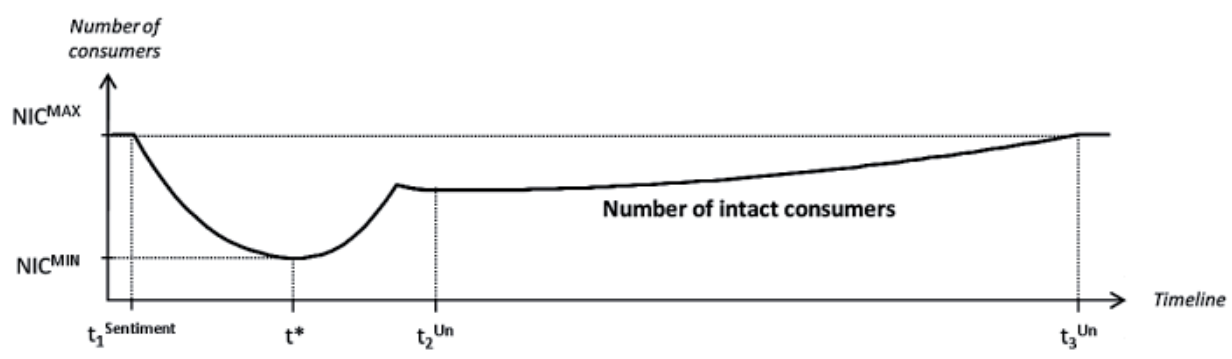

\section{Microeconomic Effects of the Car Scrapping Scheme}

\subsection{Effects of Car Scrapping Scheme's Introduction on Consumer Behaviour}

\section{Shift of income line}

The introduction of the contemporary incentive, even though conditioned by given requirements, can be from the consumer's perspective understood as a time-limited 
discount. Thanks to it, there is a shift of the slope of the income line. The actual magnitude of this shift depends particularly on the definition of goods $\mathrm{X}$, the price of the new car and the level of the incentive. The temporarily lower price of goods $\mathrm{X}$ creates an incentive for the consumer to increase its consumption, because the marginal utility stemming from this consumption does not decrease. ${ }^{15}$

It is necessary to point out that this approach cannot be applied to all consumers. For consumers, who do not exploit the incentive, the shift of the income line is just a theoretical opportunity, not an actual situation.

Graph 10

Income line shift caused by the price

change of goods $x$

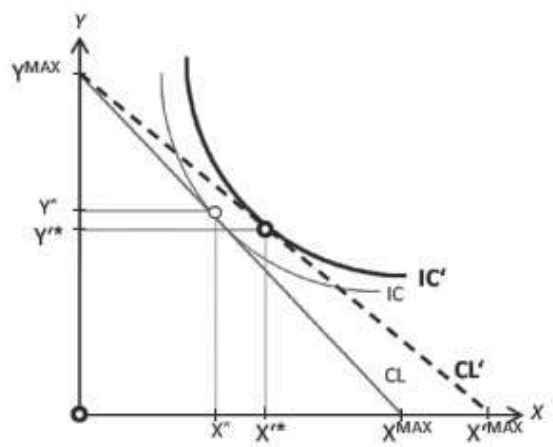

Graph 11

Shift of the indifference curves map thanks to the preference shock

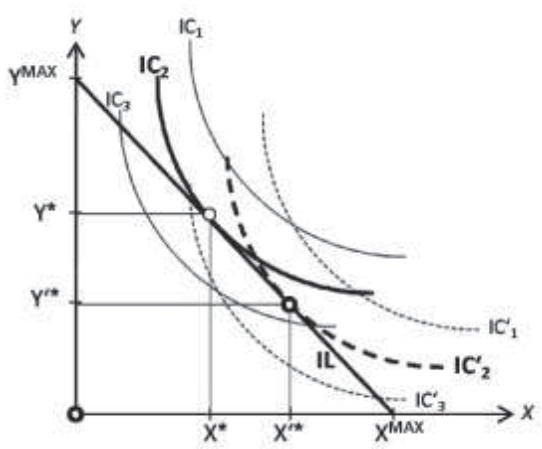

\section{Shift of indifference curves}

The consumer's preferences are by default described by the map of indifference curves, which under usual conditions don't react to the shift of the income level, consumption level, or prices of goods. However, the temporary incentive can with some consumers evoke the preferential shock, which causes the change of preferences leading to the transformation of the map of indifference curves. ${ }^{16}$

The consumers understand the incentive as a non-recurring time-limited opportunity for advantageous purchase. Such a situation thus raises their subjective utility of the consumption of the second unit of goods $X$ (purchase of a new car), while the utility stemming from consumption of goods $\mathrm{Y}$ remains intact.

The shift of preferences causes the imbalance of the consumer's equilibrium. To re-balance it, it is necessary to raise the consumption of goods $\mathrm{X}$ and to lower the consumption of goods $\mathrm{Y}$.

\subsection{Requirements for Exploitation of Car Scrapping Scheme's Incentive}

\section{Definition of goods $X$}

The goods $\mathrm{X}$ is in this analysis understood as the car ownership. The price of it is thus

15 The marginal utility stemming from the consumption of the second unit of goods X can be actually even higher than the utility coming from the consumption of the first unit, as described further.

16 See for example Andolfatto (2008), Chugh (2008), Zou (2008) 
all costs related to the ownership, not only the purchasing price. ${ }^{17}$ These costs can be split into two groups - the fixed costs, whose level is independent on the car's mileage (such as the purchase price, ${ }^{18}$ damage liability, or the toll sticker), and the variable costs, which differ according to distance travelled (such as the consumption of fuel and other liquids, service and maintenance fees, or parking fees).$^{19}$

\section{Level of consumption of goods $X$}

In case the consumer consumes one unit of car ownership (is not a purchaser of a new car), the costs sum up to certain level, which represents the price of this unit. The initial situation is marked as $\mathrm{X}^{*}$ in the graphs. The costs level (and correspondingly the one unit consumption "magnitude") can be by the consumer affected only marginally (by modifying the distance travelled - this situation happens in case of pessimist and unemployed consumers) or entirely (by selling the car). I assume that only very few consumers would end up with the extreme latter alternative, therefore I neglect it and analyse the former option only.

I further assume that the distance travelled by consumer is not a variable fluctuating freely according to the consumer's will, but it is to high extent affected by consumer's daily life (work, school, shopping, etc.). ${ }^{20}$ The change of the expenditures on consumption of goods $\mathrm{X}$ is thus limited.

Graphs 12 and 13

Constraints of goods $\mathrm{x}$ consumption (left graph) and the consumer's equilibrium in case of income line shift and application of these constraints (right chart)
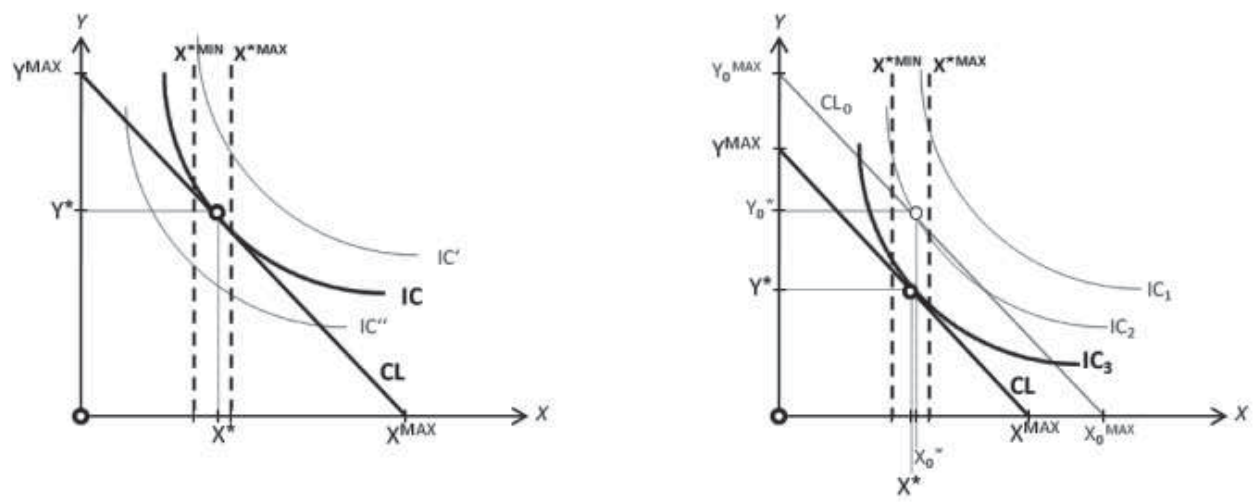

The cost analysis of car ownership suggests that consumer, who decides to purchase a new car (and who therefore temporarily consumes two units of goods $\mathrm{X}$ ), has to more than double the expenditures for goods X. This is an important constraint influencing the purchasing decision. The consumer's optimum has to lie within the range, which is graphically described in the graph below.

17 Both price and costs are for easier understanding identified on a monthly basis.

18 Purchase price calculated as a monthly payment of leasing.

19 Similar costs were identified also by Dargay (1997).

20 Centrum dopravního výzkumu (2004). 


\section{Definition of goods $Y$}

Based on the definition of goods $\mathrm{X}$ as the car ownership, the goods $\mathrm{Y}$ can be defined as all other goods that the consumer demands. The unit of consumption is then, for example, one hundredth of consumer's income.

\section{Minimum level of consumption of goods $\mathbf{Y}$}

According to the definition, the consumer can theoretically consume 100 units of goods Y, or 4 units of car's ownership (or any other number of units depending on the exact costs and consumer's income). Whereas the former solution is a viable option (even though a neglected one), the latter one is not. Goods Y include, among other, items such as accommodation, food and beverage, which must be higher than zero. Thus, there apparently is a minimum level of consumption of goods $\mathrm{Y}$, which must be reached by every consumer.

This minimum level of consumption of goods Y represents another constraint, because the consumer's equilibrium must lie above (or on) it.

\section{Graph 14}

Level of consumption of two units of goods $x$

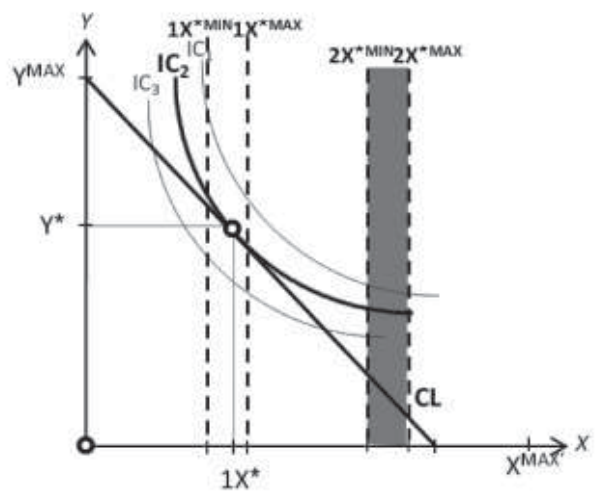

\section{Graph 15}

Minimum level of consumption of goods y

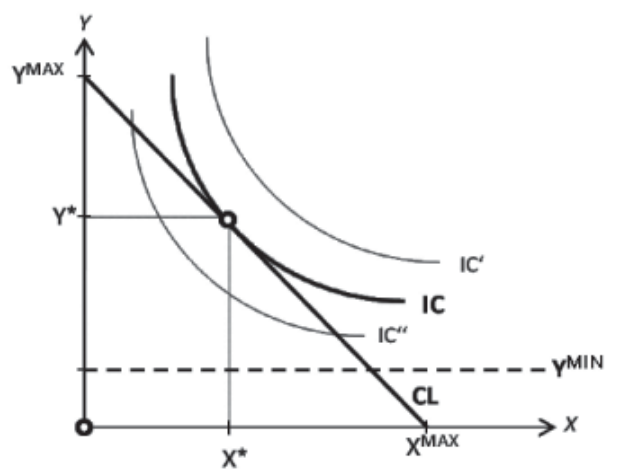

\subsection{Effects of Car Scrapping Scheme's Introduction on Particular Groups of Consumers}

\section{Pessimist consumers}

Pessimist consumers change their consumption patterns due to their negative expectations. They voluntarily lower the level of consumption, which leads to the shift of the consumption line CL. The consumption of goods $\mathrm{X}$ declines slightly (see previous chapter), whereas the consumption of goods Y sinks significantly. The consumer's equilibrium can not be located below the $\mathrm{Y}^{\mathrm{MIN}}$ line and must lie within the interval $\left\langle\mathrm{X}^{* \mathrm{MAX}} ; \mathrm{X}^{* \mathrm{MIN}}\right\rangle$. The difference between the income line IL and consumption line $\mathrm{CL}$ represents the savings. 
Graphs 16 and 17

Pessimist consumers - consumer's equilibrium before the car scrapping scheme introduction (left graph) and the shift of income/consumption line after its introduction (right graph)
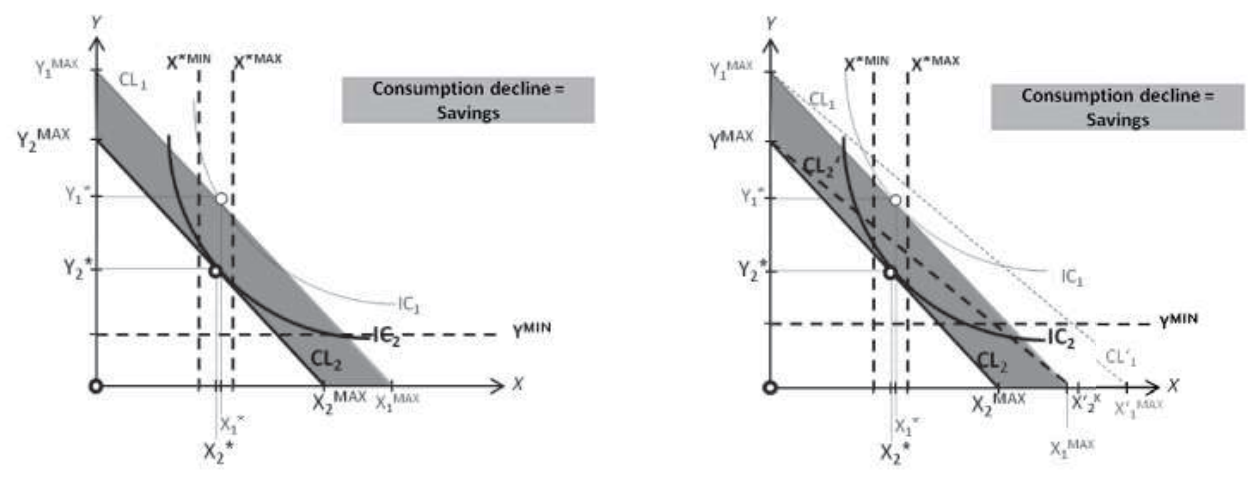

The consumption line $\mathrm{CL}_{2}$ lies beneath the income line IL, which remains on the original level $\mathrm{CL}_{1}$.

The introduction of the car scrapping scheme causes the change in the slope of the income line. This shift can be understood both as a shift of the lowered consumption line $\mathrm{CL}_{2}$, with the savings conserved, and as a shift of the original $\mathrm{CL}_{1}$.

The exploitation of the car scrapping incentive must lead to the consumption of two units of goods $\mathrm{X}$, whereas the total financial expenditure on this goods must more than double. The new consumer's equilibrium must lie on or between the lines $2 X^{* \text { MIN }}$ a $2 X^{* \text { MIN }}$, and can't lie below the line $\mathrm{Y}^{\mathrm{MIN}}$, which is within the marked tetragon.

Graphs 18 and 19

Pessimist consumers - Consumer's constraints after the car scrapping scheme introduction (left graph) and the consumer's equilibrium after its exploitation (right graph)
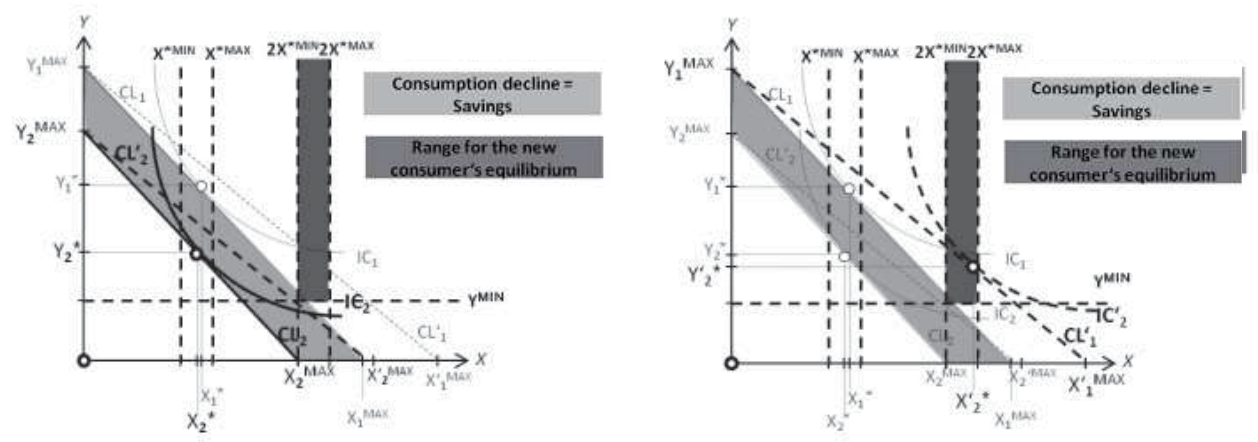

The consumption line $\mathrm{CL}_{2}$ (respectively $\mathrm{CL}_{2}{ }_{2}$ ) lies in the left graph beneath the income line IL, which remains on the level of the original $\mathrm{CL}_{1}$ (respectively $\mathrm{CL}^{\prime}{ }_{1}$ ).

The constraints of the minimum consumption of goods $\mathrm{X}$ and $\mathrm{Y}$ and the location of the decreased consumption line don't provide space for reaching the consumer's equilibrium. However, if the consumption line returns to its original position, the car scrapping incentive could be exploited under the condition that 
the preferential shock shifts the map of the indifference curves in the desired way. ${ }^{21}$

After re-gaining optimism, the consumption pattern of the pessimist consumers returns to its original level (if it has not already done so thanks to the incentive) and as the consumer's sentiment further rises, the savings generated in the previous period are consumed, which temporarily shifts the consumption line above the income line.

\section{Unemployed consumers}

Unemployed consumers are forced to change their consumption pattern due to the decline of their disposable income. Therefore, they lower the level of consumption, without any savings. The consumption of goods X lowers only slightly, whereas the decline of goods Y consumption is more significant, cannot however fall below the minimum value of $\mathrm{Y}^{\mathrm{MIN}}$.

The unemployed consumers do not have the choice of returning their consumption line back to the previous level. Therefore, the introduction of the car scrapping incentive induces a (theoretical) change of the slope of consumption line $\mathrm{CL}_{2}$ only.

If the unemployed consumers wanted to take advantage of the incentive, they would have to fulfil the requirements of more than double consumption of goods $\mathrm{X}$ and minimum consumption of goods Y. Under the given circumstance, there is no space for reaching the equilibrium and the unemployed consumers can't exploit the car scrapping incentive (see Graph 18). It makes sense that in case of a job loss and income decline, the consumer can't effort to buy a new car.

After finding a new employment, the consumers from this group change their consumption behaviour back to the original one. ${ }^{22}$

\section{Intact consumers}

The intact consumers don't react at the economy fluctuations and don't change their consumption patterns.

The introduction of the car scrapping incentive causes the shift of the slope of the consumption line. Again, the exploitation of the car scrapping incentive leads to the consumption of two units of goods X. The new consumer's equilibrium is subject to condition of double goods X consumption and of minimum consumption of goods Y (Graph 20).

\section{Graph 20}

Intact consumers - Consumer's equilibrium after exploitation of the car scrapping scheme

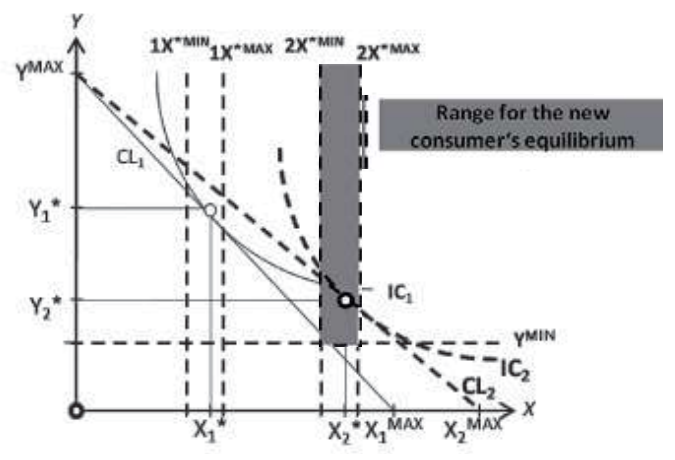

21 It is important to point out that there is an assumption, that the consumer exploits the car scrapping scheme either immediately or never.

22 I assume that by that time the car scrapping scheme is already over. 
All the mentioned constraints offer space to reach new consumer's equilibrium. The car scrapping scheme can thus be exploited by intact consumers, whose map of indifference curves shifts accordingly thanks to the preference shock.

The consumption of goods X (car ownership) of consumers, who decided to exploit the car scrapping incentive, can fluctuate within the two units range during the leasing period. Afterwards, both the consumption line and the consumption of goods $\mathrm{X}$ and $\mathrm{Y}$ return to their previous positions.

\section{Development of Aggregated Consumption}

\subsection{Number of Consumers Exploiting the Car Scrapping Scheme}

\section{Key factors influencing the interest of the consumers}

The number of consumers, who decide to exploit the car scrapping incentive, depends on four crucial factors:

- Fulfilment of the qualification conditions

- Level of the financial incentive encouraging the purchase of the new car

- Fulfilment of the microeconomic conditions (particularly the minimum consumption of goods $\mathrm{X}$ and the minimum consumption of goods $\mathrm{Y}$ )

- Desired shift of consumer's preferences

\section{Timing of the car scrapping scheme introduction}

The above mentioned analysis revealed that the target recipients of the incentive are the pessimist and the intact consumers. However, only the former ones actually increase their consumption level, the latter ones adjust their consumption structure. Therefore, the optimal timing of the car scrapping scheme should address as many pessimist consumers as possible.

As the assumption claims that the number of pessimist consumers follow a concave trajectory, the best time for the introduction of the scheme can be understood as $\mathrm{t}_{1}$ Sentiment , when the number of pessimist consumers starts to grow. Ideally, the car scrapping scheme ends in time $t_{2}^{\text {Sentiment }}$, which is the peak of the number of the pessimist consumers.

Under these circumstances the number of consumers that decide to exploit the car scrapping scheme can be graphically describes as follows:

Graph 21

Pessimist consumers - Number of car scrapping scheme exploiting consumers

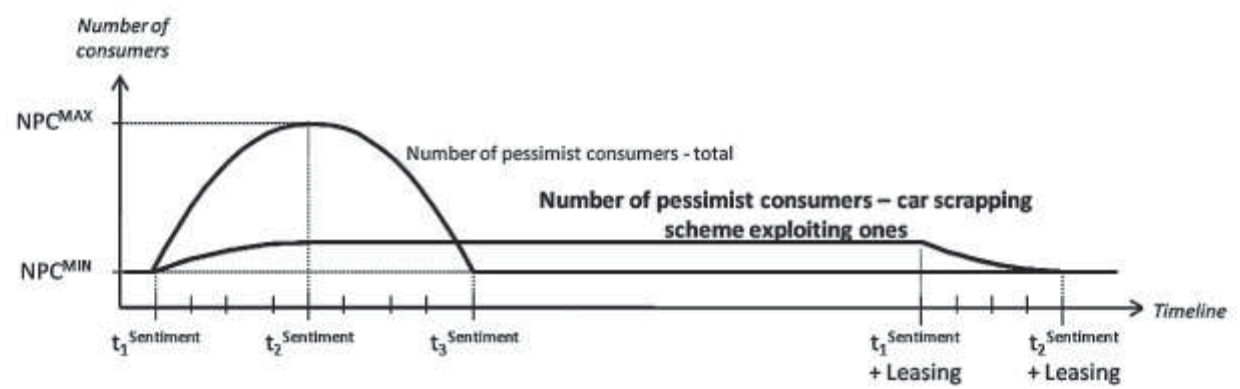


Graph 22

Intact consumers - Number of car scrapping scheme exploiting consumers

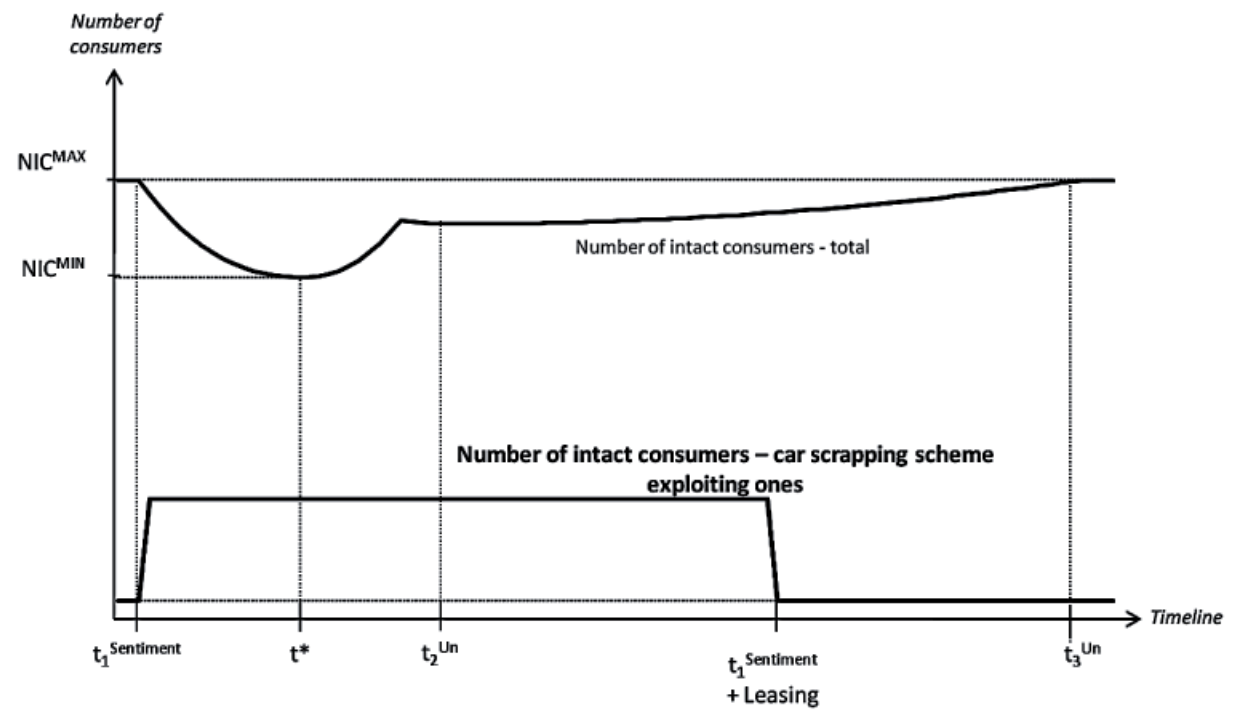

The exact number of attracted consumers depends mainly on the four key factors mentioned above. It can be assumed that the number of intact consumers who decide to exploit the incentive will be relatively higher than the number of pessimist consumers, as the intact consumers do not need to ,give up“ the savings, they just re-structure their consumption.

\section{Aggregate consumption without the car scrapping scheme}

With the development of the consumers numbers assumed above, the aggregate consumption starts to decline in time $t_{1}$ Sentiment. The global minimum of the consumption is reached in $t^{*}$, within the interval $\left(t_{2}{ }^{\text {Sentiment; }} t_{2}{ }^{\text {Un }}\right)$. The second local minimum follows in time $t^{6}$, when all the savings accumulated by the pessimist consumers have been spent and the number of unemployed consumers still exceeds the original value.

\section{Graph 23}

Aggregate consumption without the car scrapping scheme

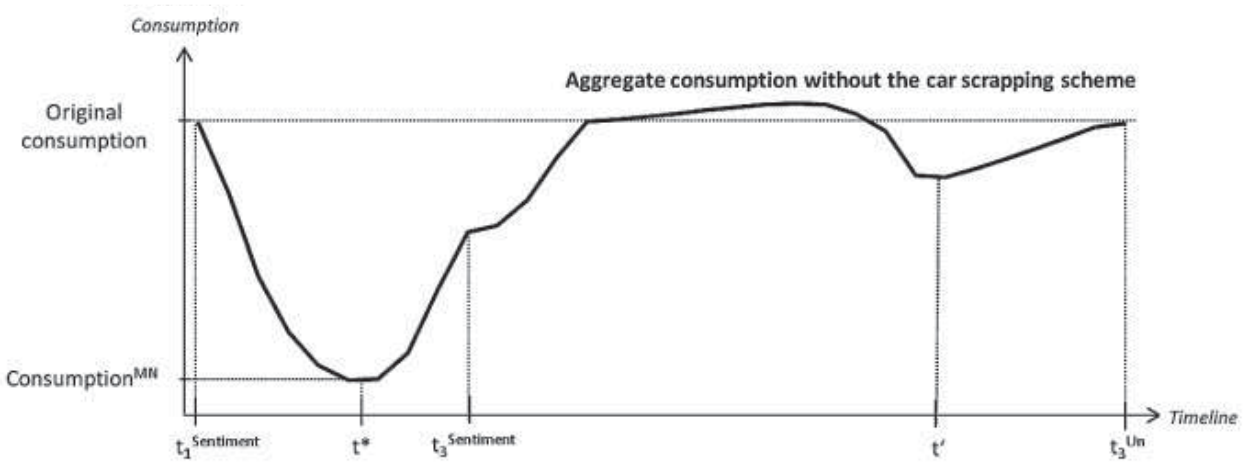


As discussed above, the optimum time for the application of the car scrapping scheme is interval $\left\langle\mathrm{t}_{1}{ }^{\text {Sentiment }} ; \mathrm{t}_{2}{ }^{\text {Sentiment }}\right\rangle$. During this time, the incentive can be targeted on the highest number of the pessimist consumers, whose behavior is crucial to influence the aggregate consumption. The global minimum of the aggregate consumption boosted by the car scrapping scheme is reached in time $t^{*}$. The second local minimum follows after all the saved means of pessimist consumers have been consumed in time $t$ ". The return of the aggregate consumption to the original level takes longer time with the car scrapping scheme, as the number of pessimist consumers, who save their money, is lower (decreased by the number who decide to exploit the car scrapping scheme), and therefore there is less money to spend after the pessimism fades away.

Graph 24

Aggregate consumption with the car scrapping scheme

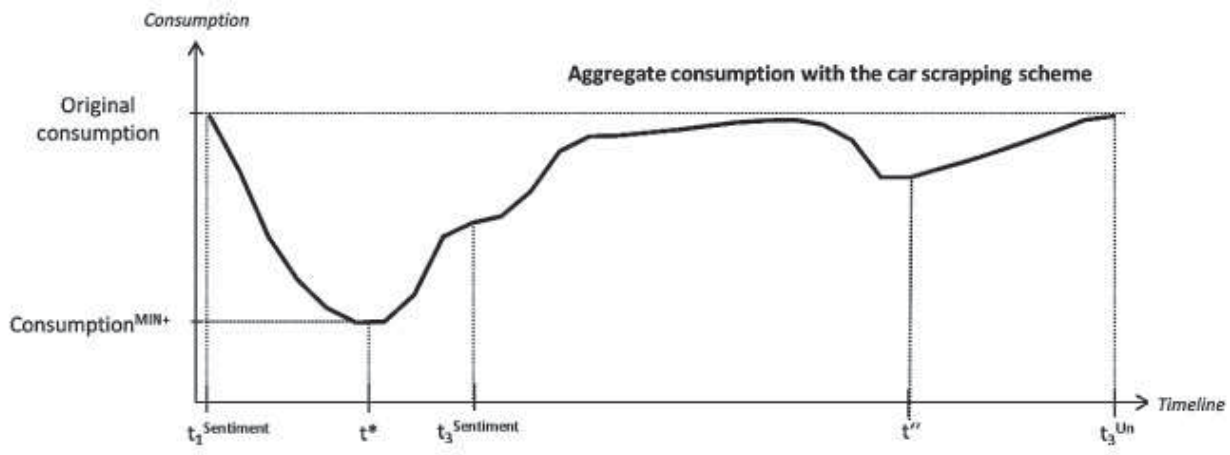

\section{Effects of the introduction of the car scrapping scheme}

\subsection{Proven effects}

\section{Mitigation of the deepest decline of the aggregate consumption}

The comparison of the aggregate consumption development with and without the car scrapping scheme proves that its introduction mitigates the trough of the consumption decline in time $t^{*}$, when the combined number of pessimist and unemployed consumers peaks.

\section{Graph 25}

Comparison of aggregate consumption with and without car scrapping scheme

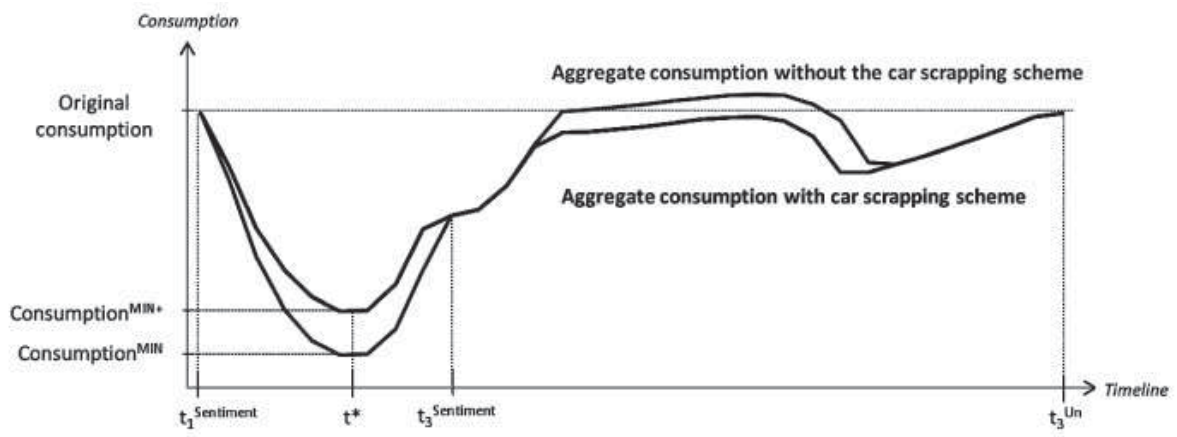




\section{Slower return to previous level of consumption}

The trough mitigation is in the following phase "re-paid" by the slower aggregate consumption growth and longer time needed for the recovery to the original consumption level.

\section{Change of savings level}

The car scrapping scheme introduction has direct influence on the level of savings. Whereas without the scheme all pessimist consumers lower their consumption and raise savings, in the case of its introduction the number of saving pessimist consumers sinks.

\section{Graph 26}

Comparison of aggregate savings and their subsequent consumption with and without the car scrapping scheme

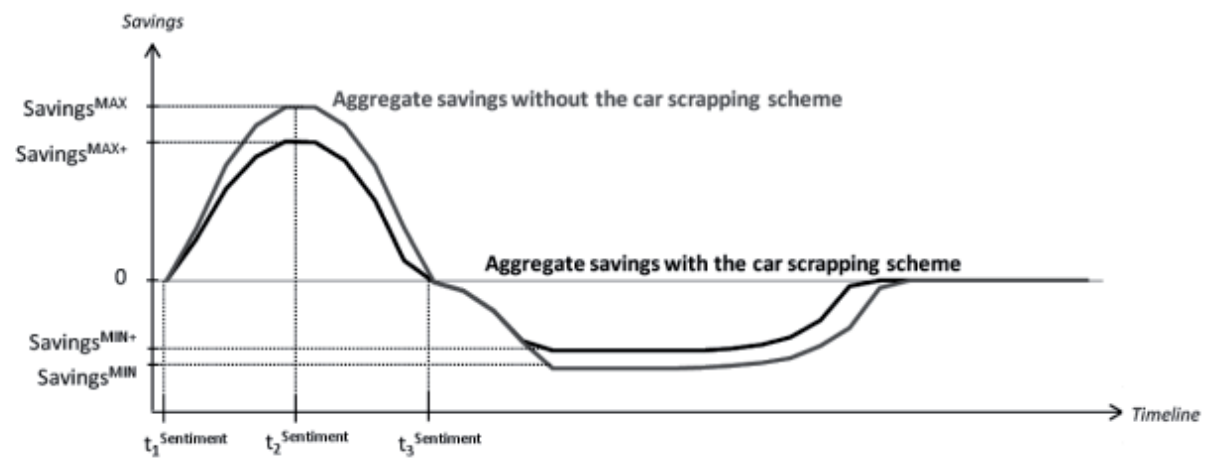

\section{Change in the structure of goods consumed}

The introduction of the car scrapping scheme encourages higher consumption of goods $\mathrm{X}$ (car ownership) at the expense of goods Y consumption (other goods). In other words, this tool intentionally supports the consumption in one field at the costs of all the other ones.

\section{Consumption of goods $\mathrm{X}$}

Due to the lower elasticity of goods X consumption, its level decreases only slightly. After the scrapping scheme introduction, the level of consumption of goods $\mathrm{X}$ booms. In the following phase, the consumption level stagnates, or slightly grows. The sudden decline of the expenditures on goods X comes at the time when the proposed leasing scheme is over.

Graph 27

Comparison of consumption of goods $\mathrm{x}$ with and without car scrapping scheme

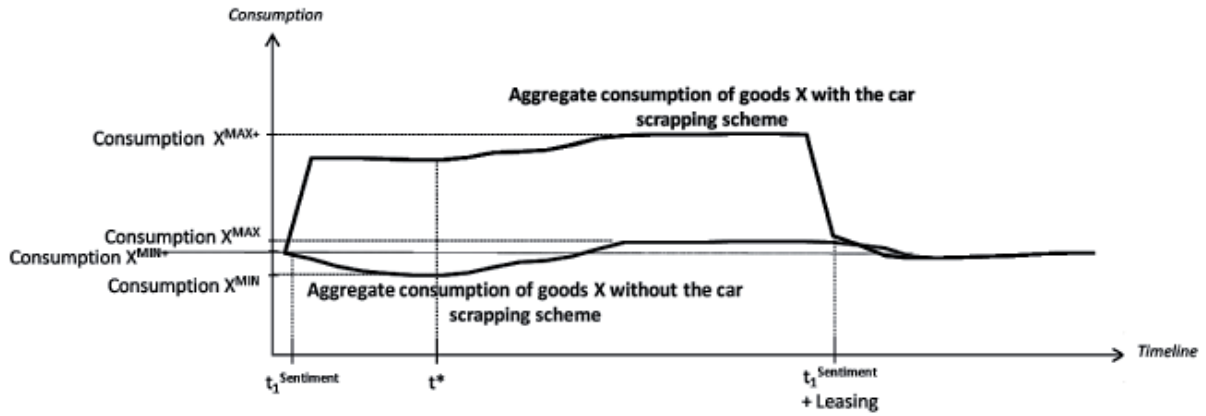




\section{Consumption of goods $Y$}

The consumption of goods $\mathrm{Y}$, which is already affected by the decline significantly, sinks deep at the moment of the scrapping scheme introduction, which is exploited by the intact consumers. In the following phase, the consumption further slowly decreases, until it reaches the trough. Adversely to the development of unemployment consumers, the consumption of goods Y slightly increases before booming at the end of the leasing schemes of consumers, who took advantage of the car scrapping scheme.

Graph 28

Comparison of expenditures for the consumption of goods $y$ with and without car scrapping scheme

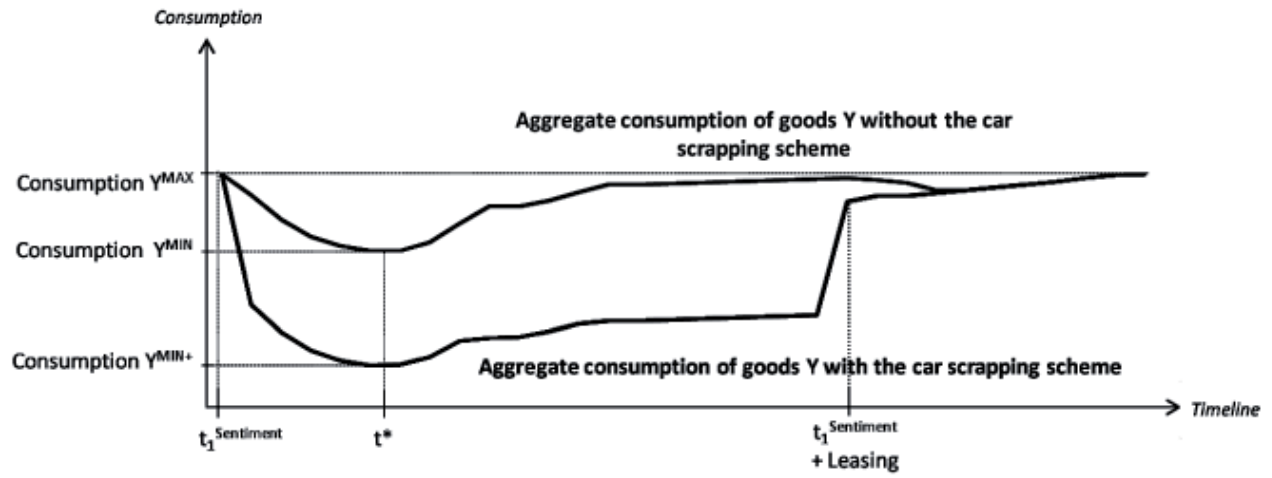

\subsection{Further Potential Effects}

The crucial analysis to be executed before the introduction of the car scrapping scheme is the assessment of the total economic and social benefits and costs, and its following discussion. Similarly, it is necessary to evaluate the difference between the expected and actual effects after the car scrapping scheme is over. These analyses should, among other, include the following fields:

- Effect on the total environmental impact of the car transportation

- Effect on the traffic safety

- Effect on the total employment

- Effect on the consumer sentiment recovery

- Effect on the consumption of new cars after the car scrapping scheme

\section{Conclusion}

The financial crisis started in 2007 in the USA triggered a global economic decline and caused economic recessions in many countries worldwide. The automotive industry was one of the many industries seriously hit by the crisis. Decreasing sales of new cars, especially in the most developed countries, and the proclaimed fundamentality of the influence of automotive industry on the national economies were the main reasons for the introduction of a program focused on the intensive contemporary increase of 
aggregate consumption in the time of economic recession, which is referred to as the car scrapping scheme.

This scheme, as a special incentive to purchase a new car, was applied in different ways, most commonly as a direct financial support or an ex-post tax relief. Its exploitation was conditioned by scrapping an old car of the applicant. The main idea behind the program was that the temporary incentive would support the car sales, thus leading to higher aggregate consumption.

The purpose of this paper was to assess, whether the introduction of the incentive can serve as an efficient tool to stimulate the demand in the time of economic decline. As a research method, the microeconomic analysis of consumer behaviour was applied.

The paper brings proof that the car scrapping scheme can mitigate the maximum decline of the aggregate consumption, thanks mainly to the shift of the consumption lines and of the maps of the indifference curves among consumers, who understand the program as a non-recurring, temporary and advantageous incentive. As expected, it was also proved that the car scrapping scheme shifts the consumption in time, which leads to a lower consumption in the eventual part of the analysed period. Furthermore, the effects of the program include changes in the aggregate savings, as well as modifications in the composition of goods consumed.

Among the most important effects that weren't tracked belongs the influence on the overall environmental impact of road traffic, the rising safety of the car transportation, the employment security, or the influence on the car sales after the car scrapping scheme.

Even though it was proved that the introduction of the car scrapping scheme may serve as a tool to support the aggregate consumption in the time of the economic decline due to the complexity of the car scrapping scheme's impacts the assessment of its actual introduction remains more a political than economic task.

\section{References}

ACEA (2009a), Fleet Renewal Schemes Can Soften the Impact of the Recession. European Automobile Manufacturers' Association. November 2009.

ACEA (2009b), New Vehicle Registrations - Monthly Figures. European Automobile Manufacturers' Association. Statistics available in December 2009 at http://www.acea.be/index.php/collection/ statistics.

Andolfatto, D. (2008), Macroeconomic Theory and Policy. 2nd edition. Simon Fraser University.

Biggs, M. (2009), "Self-fulfilling Prophecies." In The Oxford Handbook of Analytical Sociology, Chapter 13. Oxford University Press.

Blanchard, O. (2006), Macroeconomics. Fourth Edition. Massachusetts Institute of Technology. Pearson Education Limited. ISBN 0131860267.

Brown, S., Taylor, K. (2006), "Financial Expectations, Consumption and Saving: A Microeconomic Analysis." Sheffield Economic Research Paper Series. Department of Economics, University of Sheffield. May 2006.

Browning, M., Lusardi, A. (1996), "Household Saving: Micro Theories and Micro Facts." Journal of Economic Literature. Volume 34, Issue 4.

BAFA (2009), Richtlinie zur Förderung des Absatzes von Personenkraftwagen. Bundesamt für Wirtschaft und Ausfuhrkontrolle. Available in December 2009 at http://www.bafa.de/bafa/de/ wirtschaftsfoerderung/umweltpraemie/dokumente/foederrichtlinie_umweltpraemie.pdf 
Centrum dopravního výzkumu (2004), Možnosti ovlivňování chování účastníků dopravního provozu. February 2004.

Centrum dopravního výzkumu (2005), Jízdní výkony a účel používání automobilu. June 2005.

Claessens, S., Kose, M. A., Terrones, M. E. (2008), "What Happens during Recessions, Crunches and Busts?" IMF Working Paper. WP/08/274. International Monetary Fund, Research Department. December 2008.

Council of Economic Advisors (2009), Economic Analysis of the Car Allowance Rebate System ("Cash for Clunkers"). Executive Office of the President of the United States. Published on September 10, 2009.

Dargay, J., Gately, D. (1997), “Income's Effect on Car and Vehicle Ownership, Worldwide: 1960-2015.” C. V. Starr Center for Applied Economics. New York University. February 1997.

Dion, D. P. (2006), "Does Consumer Confidence Forecast Household Spending?" Personal RePEc Archive, Munich. November 2006.

Federal Reserve Bank of Chicago (2008), "Chicago Fed Letter-Trends in Consumer Sentiment and Spending." No. 262. The Federal Reserve Bank of Chicago. May 2008.

Federal Reserve Bank of San Francisco (2008): FRBSF Economic Letter. No. 2008-19. Federal Reserve Bank of San Francisco. June 2008.

Ferguson, C. E. (1972), Microeconomic Theory. Third Edition. Texas A\&M University. Richard D. Irwin, Inc. Library of Congress Catalog Card No. 71-168295.

Hashish, I., Hai, H. K., Feinmann, C., Harris M. (1988), "Reduction of Postoperative Pain and Swelling by Ultrasound Treatment: A Placebo Effect.” Pain, 1988; 33, pp. 303-311.

Hospodářská komora ČR (2009), Analýza zavedení šrotovného $v$ ČR. Hospodářská komora ČR and Institut rozvoje podnikání VŠE Praha: ČR. May 2009.

Höpfner, U. (2009), Abwrackprämie und Umwelt-eine erste Bilanz. Institut für Energie- und Umweltforschung Heidelberg GmbH. August 2009.

Chugh, S. K. (2008), "Preference Shocks." Lecture Notes for Spring Semester 2008. University of Maryland. Spring 2008.

Knotek II, E. S., Terry, S. (2009), "How Will Unemployment Fare following Recession?" Economic Review, 2009, Issue Q III. Federal Reserve Bank of Kansas City.

Läufer, N. K. A. (2009), "Mikro- und Makroökonomische Effekte der Abwrackprämie.” Wissenschaft für die Praxis. Wirtschaftsdienst, volume 89, issue 6. Springer. June 2009.

Li, Q. (2006), "The Self-fulfilling Prophecy of the Human Nature-Hypothesis by managers." Linyi Normal University. August 2006.

Mankiw, N. G. (2007), Macroeconomics. Sixth Edition. Harvard University. Worth Publishers. ISBN-13: 978-0-7167-6213-3.

MHSR (2009), Infomácia o priebehu čerpania dotácie na nákup nového vozidla, při súčasnej likvidách starého vozidla $k$ 31. 07. 2009. Ministerstvo hospodárstva Slovenskej republiky.

NBR (2008), "Determination of the December 2007 Peak in Economic Activity." National Bureau of Economic Research, December 2008.

Nicholson, W. (1989), Microeconomic Theory. Basic Principles and Extension. Fourth Edition. Amherst College. The Drydenn Press. ISBN 0-03-021669-9.

Rosenwald, M. S. (2009), "When you're Flush, but Acting Flat Broke-Social Cues that Can Drive a Downturn." Washington Post. April 2009.

Sdružení automobilového průmyslu (2009), "Přehled výroby a odbytu vozidel domácích výrobců - údaje za rok 2009." Statistics available in December 2009 at http://www.autosap.cz/default2. asp? page $=\{4$ A86501A-BBD5-4B8F-AE57-397BC8051C9A $\}$.

University of Michigan (2009), "Surveys of consumers - Index of consumer sentiment." Available in December 2009 at http://www.sca.isr.umich.edu/.

Zou, N. N, Hobbs, J. E. (2008), "Modelling Reference-dependent and Labelling Effects in Consumers' Functional Food Choices." Project Report. University of Saskatchewan. January 2008. 